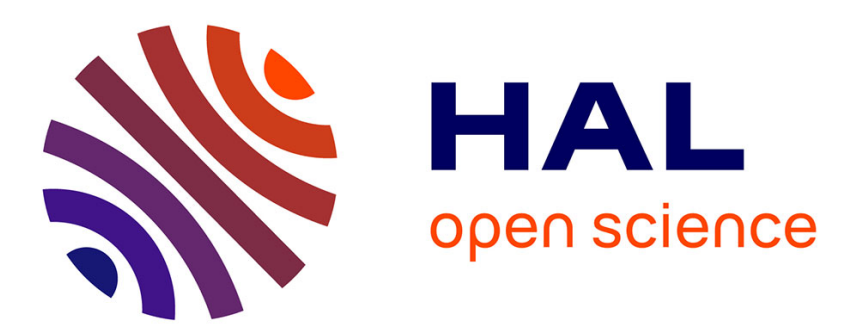

\title{
Possible evidence for a connection between methyl iodide emissions and Saharan dust
}

J. Williams, V. Gros, E. Atlas, K. Maciejczyk, A. Batsaikhan, H. Schöler, C. Forster, B. Quack, N. Yassaa, R. Sander, et al.

\section{- To cite this version:}

J. Williams, V. Gros, E. Atlas, K. Maciejczyk, A. Batsaikhan, et al.. Possible evidence for a connection between methyl iodide emissions and Saharan dust. Journal of Geophysical Research, 2007, 112 (D7), 10.1029/2005JD006702 . hal-03117218

\author{
HAL Id: hal-03117218 \\ https://hal.science/hal-03117218
}

Submitted on 21 Jan 2021

HAL is a multi-disciplinary open access archive for the deposit and dissemination of scientific research documents, whether they are published or not. The documents may come from teaching and research institutions in France or abroad, or from public or private research centers.
L'archive ouverte pluridisciplinaire HAL, est destinée au dépôt et à la diffusion de documents scientifiques de niveau recherche, publiés ou non, émanant des établissements d'enseignement et de recherche français ou étrangers, des laboratoires publics ou privés. 


\title{
Possible evidence for a connection between methyl iodide emissions and Saharan dust
}

\author{
J. Williams, ${ }^{1}$ V. Gros,${ }^{1,2}$ E. Atlas,${ }^{3}$ K. Maciejczyk, ${ }^{4}$ A. Batsaikhan, ${ }^{4}$ H. F. Schöler ${ }^{4}$ \\ C. Forster, ${ }^{5}$ B. Quack, ${ }^{6}$ N. Yassaa, ${ }^{1,7}$ R. Sander, ${ }^{1}$ and R. Van Dingenen ${ }^{8}$
}

Received 23 September 2005; revised 27 June 2006; accepted 18 October 2006; published 3 April 2007.

[1] Methyl iodide has been measured during two field campaigns in the Atlantic region in 2002. The first took place in July-August at $2300 \mathrm{~m}$ on the island of Tenerife, while the second was a shipborne, east-west crossing of the Tropical Atlantic at $10^{\circ} \mathrm{N}$ in October-November of the same year. Both campaigns were periodically impacted by dust, advected from Africa in trade winds. Unexpectedly, during these dust events, methyl iodide mixing ratios were observed to be high relative to other times. Backward calculations with the particle dispersion model FLEXPART show the origin of the dust storms as Mauritania and southern Algeria for the ground- and ship-based campaigns, respectively. The dust-laden air traveled from its source above the marine boundary layer to the measurement region. On the basis of the field data correlations and the simulations, we suggest that dust-stimulated emission of methyl iodide has occurred. To test this hypothesis, dust samples were collected from the identified source regions and added to filtered Atlantic seawater. This rapidly produced methyl iodide. Further tests established that the addition of iodide increased the yield and that iodide with $\mathrm{H}_{2} \mathrm{O}_{2}$ was greater still. This was found for both sterilized and nonsterilized samples. We conclude that there is an abiotic methyl iodide production mechanism that can occur via substitution, analogous to those in soil, rather than radical recombination. This may occur when dust contacts seawater containing iodide or when marine water vapor condenses on dust containing iodide. This hypothesis appears to be consistent with recent long-term methyl iodide data sets from Tasmania and may help resolve current uncertainties in the iodine cycle.

Citation: Williams, J., et al. (2007), Possible evidence for a connection between methyl iodide emissions and Saharan dust, J. Geophys. Res., 112, D07302, doi:10.1029/2005JD006702.

\section{Introduction}

[2] The main source of atmospheric methyl iodide $\left(\mathrm{CH}_{3} \mathrm{I}\right)$ is the ocean [Carpenter, 2003; Blake et al., 1999; Moore and Groszko, 1999]. In coastal regions methyl iodide can be produced directly from macro and micro algae in the surface mixed layer [Baker et al., 2000; Carpenter et al., 2000; Scarratt and Moore, 1999]. However, in the vast oligotrophic open ocean, a primarily photochemical rather than

\footnotetext{
${ }^{1}$ Max Planck Institute for Chemistry, Mainz, Germany.

${ }^{2}$ Now at Laboratoire des Sciences du Climat et de l'Environnement, Gif sur Yvette, France.

${ }^{3}$ Rosenstiel School of Marine and Atmospheric Science, University of Miami, Miami, Florida, USA.

${ }^{4}$ Institute of Environmental Geochemistry, University of Heidelberg, Heidelberg, Germany.

${ }^{5}$ Norwegian Institute for Air Research, Kjeller, Norway.

${ }^{6}$ Forschungsbereich Marine Biogeochemie, Leibniz Institut für Meereswissenschaften, Kiel, Germany.

${ }^{7}$ Also at Faculty of Chemistry, University of Sciences and Technology Houari Boumediene, Algiers, Algeria.

${ }^{8}$ Institute for Environment and Sustainability, Joint Research Centre, European Commission, Joint Research Centre, Ispra, Italy.

Copyright 2007 by the American Geophysical Union. 0148-0227/07/2005JD006702\$09.00
}

biological production pathway has been proposed [Moore and Zafiriou, 1994]. Abiotic production driven by light is supported by observations in surface waters [Happell and Wallace, 1996; Bell et al., 2002], while transport to the atmosphere has been shown to be correlated to sea surface temperature [Yokouchi et al., 2001]. Recent shipborne incubation experiments in the Tropical Atlantic involving natural seawater that had been filtered or poisoned indicated that methyl iodide production had no direct dependence on biological activity [Richter and Wallace, 2004]. The latter work concluded, however, that the mechanistic pathway of methyl iodide production in the ocean is not yet fully understood.

[3] After emission to the atmosphere, methyl iodide can be photolyzed or oxidized by the HO radical, to produce iodine radicals. Its relatively short lifetime (ca. 1 week) has led to it being used as a tracer for marine influence in model studies of vertical mixing [Bell et al., 2002]. Iodine produced from methyl iodide and other short-lived iodocarbons plays many important roles in marine boundary layer chemistry, influencing ozone destruction, the oxidizing capacity of the troposphere, denoxification, and particle formation [Vogt et al., 1999; Carpenter, 2003; O'Dowd et al., 2002]. The ultimate fate of gas phase iodine is abstraction to aerosol particles as iodide $\left(\mathrm{I}^{-}\right)$and iodate $\left(\mathrm{IO}_{3}^{-}\right)$. 
Recent speciated measurements of both $\mathrm{I}^{-}$and $\mathrm{IO}_{3}^{-}$in Tropical Atlantic aerosol showed that the $\mathrm{I}^{-} / \mathrm{IO}_{3}^{-}$ratios measured cannot be reproduced by current models of aerosol iodine chemistry [Baker, 2004]. Further studies of methyl iodide are evidently required to better understand the iodine cycles in both the air and the seawater.

[4] In this study we present two field measurement data sets of methyl iodide, collected in 2002 between $0-30^{\circ} \mathrm{N}$ in Atlantic air. The first field campaign (MINATROC) was completed in July and August at the $2300 \mathrm{~m}$ high measurement station Izaña, on Tenerife $\left(28^{\circ} \mathrm{N}, 16^{\circ} \mathrm{W}\right)$, and the second (Meteor 55), from a research ship during a west to east crossing of the Atlantic at $10^{\circ} \mathrm{N}$ latitude [Wallace and Bange, 2004]. For periods of several days in both campaigns, a major dust event of Saharan origin impacted the point of measurement. An unexpected finding during the high dust events in both campaigns was that the methyl iodide mixing ratios were found to be higher than in low dust conditions. These events are analyzed with a particle dispersion model and supplementary laboratory experiments using dust and filtered seawater. Possible explanations for the apparent covariance of methyl iodide and dust are discussed in this paper.

\section{Methods}

[5] In both campaigns methyl iodide was measured from whole air samples collected every four hours in stainless steel canisters and subsequently analyzed in the laboratory by a gas chromatograph-mass spectrometer system (GC-MS; Agilent Technologies), within 3 months of sampling. Storage tests have not shown significant changes of the mixing ratios of the methyl iodide during this period. Canisters were filled by the following procedure: flushing four times and then pressurizing to 3 bar using a metal bellows pump. Analyses at the Max Planck Institute (MINATROC, Tenerife campaign) were carried out using a GC-MS with cryogenic preconcentration of the VOCs at $-72^{\circ} \mathrm{C}$, separation on a DB-5 column and detection by a quadrupole mass spectrometer (Single Ion Mode). The system allows the quantification of various hydrocarbons and halocarbons and its characteristics have been described in detail elsewhere [Gros et al., 2003]. Calibration was performed at least twice a day against a working standard calibrated at the National Center for Atmospheric Research (NCAR). Therefore all measurements presented here are calibrated on the NCAR calibration scale. The detection limit for methyl iodide was $0.1 \mathrm{pmol} / \mathrm{mol}$, and the overall uncertainty estimated to be better than $15 \%$. A set of 132 canisters was collected on the Meteor 55 campaign, by NCAR. The NCAR canisters were analyzed by GC-MS, and the analytical system is described in detail elsewhere [Schauffler et al., 2003].

[6] The laboratory analyses were made from either $20 \mathrm{ml}$ headspace vials with a gas chromatograph-electron capture detector, GC-ECD (Fison HRGC 8265) or a purge and trap GC-MS (Tekmar LSC 2000/Varian Star 3400 cx/Varian Saturn 2000). To investigate the abiotic formation of methyl iodide in samples of Lanzarote (Canary Islands) soil dust, $4 \mathrm{~g}$ of sample was suspended in $10 \mathrm{ml}$ of demineralized, bidistilled and UV irradiated water in $20 \mathrm{ml}$ headspace vials, which were capped immediately after sample preparation.
The UV irradiation was performed with an Elgastat UHQPS (Elga, UK) with a Silvania UV G4W lamp to destroy any organic species in the water. The vials were agitated in the dark for 24 hours before the gas phase was analyzed for $\mathrm{CH}_{3} \mathrm{I}$ with a GC-ECD or a purge and trap GC-MS. Furthermore, iodide as potassium iodide $(\mathrm{KI})$ and oxidants as hydrogen peroxide $\left(\mathrm{H}_{2} \mathrm{O}_{2}\right)$ were added to selected vials to study their influence on the yield of the reaction. In addition, two samples were sterilized at $120^{\circ} \mathrm{C}$ in an autoclave so that a microbiological contribution to the production of methyl iodide could be excluded. The sensitivity experiments were conducted with the fine fraction $(\mathrm{d}<0.125 \mathrm{~mm})$ of fourteen soil dust samples collected from Lanzarote, which is situated directly downwind from the main sources of Saharan dust. The geochemical characterization of the samples revealed that they were chemically comparable to African dust samples. Lanzarote samples were preferred for the experiments, as this dust had already undergone aeolian transport from the Sahara.

\section{Results}

\subsection{Tenerife Data (MINATROC)}

[7] In July-August 2002, methyl iodide measurements were carried out at Izaña, Tenerife, to assess potential interactions between mineral dust aerosol and tropospheric chemistry. The station is situated on a mountain ridge on the island of Tenerife at $2360 \mathrm{~m}$ above sea level (asl., $28^{\circ} 18^{\prime} \mathrm{N}$, $\left.16^{\circ} 29^{\prime} \mathrm{W}\right)$. During the campaign a dense Saharan dust plume, with aerosol masses exceeding $500 \mu \mathrm{g} \mathrm{m}^{-3}$, persisted for 3 days; see Figures $1 \mathrm{a}$ and $1 \mathrm{~b}$. Several smallerscale events are also apparent. The methyl iodide mixing ratios (see also Figures 1a and 1b) appear to be elevated in each of the dust events, although it is clear from the variation that this is not the only factor affecting this species. By day, under normal dust free conditions, marine boundary layer air is transported upslope to the site. In contrast at night, an inversion at $1.5 \mathrm{~km}$ serves to isolate the site from the ocean. During the dust event the effect of the inversion was weaker and air from the marine boundary layer can be mixed up to the site more effectively. This can be seen in the relative humidity signal, which increases during the dust event. Note that the humidity was also high between 2 August and 5 August, when methyl iodide was elevated even in the absence of dust (see Figures 1a and 1b). This will be examined further in the discussion section. The prevailing wind during the measurement period was northwest; however, during the dust event the wind was from the southeast. It is important to note that the wind turned southeasterly for 1.5 days before the dust arrived, and during this time methyl iodide remained low indicating negligible local sources from this wind direction (see Figure 1b; see expanded section). Although the widely used term "dust storm" implies high wind speeds, it should be noted that the arrival of the dust was not associated with significantly enhanced wind speeds; see expanded section of Figure 1a. Indeed, for the entire period shown in Figures $1 \mathrm{a}$ and $1 \mathrm{~b}$ before the dust event, the wind speed was on average higher $\left(8.9 \mathrm{~m} \mathrm{~s}^{-1}\right)$ than during the dust event $\left(7.7 \mathrm{~m} \mathrm{~s}^{-1}\right)$, although afterward the wind speed was on average $5.3 \mathrm{~m} \mathrm{~s}^{-1}$. Aerosol index images from the TOMS satellite indicated that this dust plume originated 


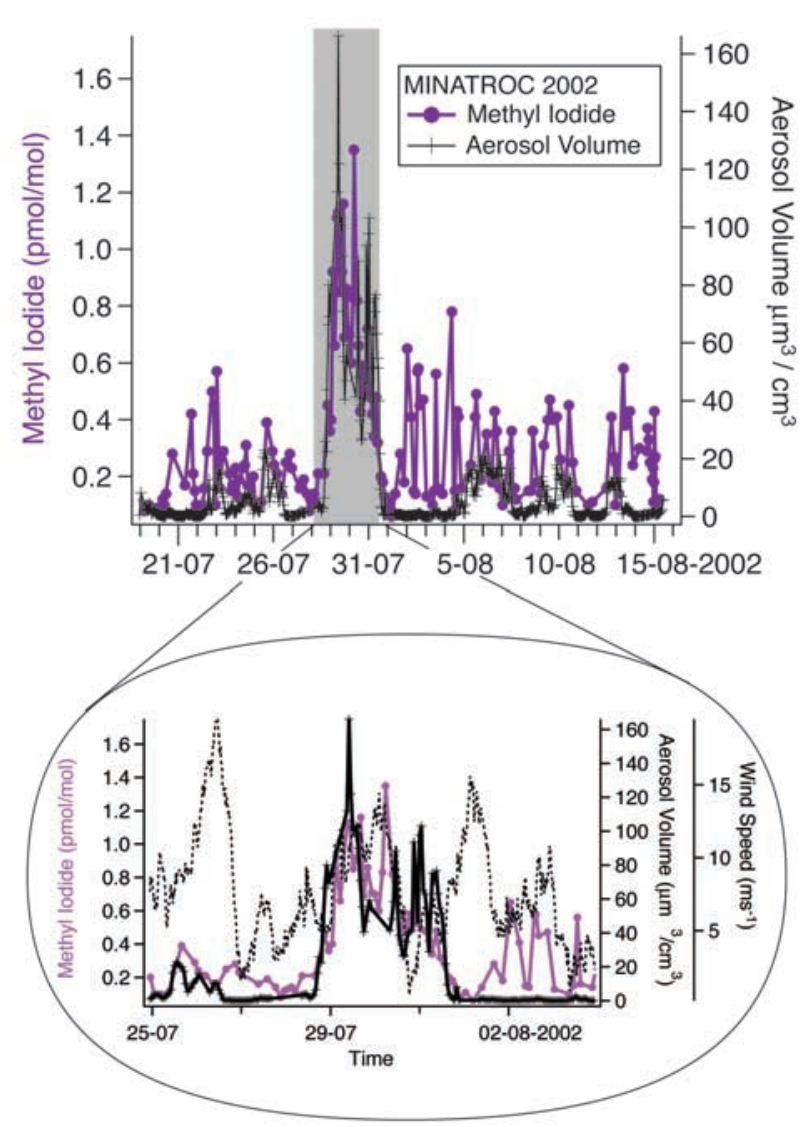

Figure 1a. Methyl iodide mixing ratios measured at Izaña, Tenerife, plotted with aerosol volume. The period of the main dust event is marked with grey shading.

in southwestern Algeria and its border region with Mali and Mauritania. Backward simulations with the particle dispersion model FLEXPART (described in detail below) suggest that the air masses were lifted over the boundary layer from between 500 and $1500 \mathrm{~m}$ above ground level to the measurement altitude of about $2.5 \mathrm{~km}, 2.5$ to 3 days before arrival at the Izaña measurement station, and originate more to the southwest in Mauritania. Lidar measurements indicate that the Saharan dust plume at Izaña extended from the sea surface to an altitude of about $7 \mathrm{~km}$ (G. P. Gobbi, personal communication, 2003).

\subsection{Tropical Atlantic Ship Data (Meteor 55)}

[8] In the same year, methyl iodide measurements were also made on Cruise 55 of the research ship Meteor to the Tropical Atlantic (October-November 2002). The ship steamed from Curacao $\left(69^{\circ} \mathrm{W}\right)$ to Cameroon $\left(9^{\circ} \mathrm{E}\right)$ approximately along $10^{\circ} \mathrm{N}$. During the cruise the Inter Tropical Convergence Zone (ITCZ) lay at about $5-6^{\circ} \mathrm{N}$ [Williams et al., 2004]. Although instrumentation for measuring aerosol loading at high frequency was not operated on this cruise, the ship's visibility measurement can be used to see when the ship was engulfed in the dust event. The visibility measurement indicates the range of sight from the bridge and is determined every 10 seconds by the attenuation of light over $2 \mathrm{~m}$. Dust and rain events both cause the visibility to drop markedly; see Figure 2. In periods of high dust the visibility remains suppressed for a long period (e.g., 2526 October and 3-11 November) whereas rain events tended to be short (28 October). This interpretation of the visibility signal tallied with on-board observations of dust on the decks and redder sunsets. Just as in the Izaña data, the methyl iodide measured in the marine boundary layer was elevated in dust events relative to low dust conditions; see Figure 2. The effect is less clearly seen in the ship data since natural variability in methyl iodide emissions from the ocean tend to mask the effect. Nonetheless, there are several events where methyl iodide appears to vary with dust loading. At the beginning of the campaign, at the first encounter with dust in the western Atlantic (event A in Figure 2), methyl iodide peaks sharply. Furthermore, the sharp transitions from high dust to low dust on 26 October (marked by the letter B) and from low dust to high dust on 3 November (marked by the letter C) are clearly demarcated in the methyl iodide mixing ratios. The events encountered by ship named events $\mathrm{A}, \mathrm{B}$, and $\mathrm{C}$ were all measured within a wind direction sector $45-100^{\circ}$. A shift to more northerly winds occurred around midnight on the 5 November, after the onset of dust event $\mathrm{C}$. Also plotted in Figure 2 are the mixing ratios of bromoform $\left(\mathrm{CHBr}_{3}\right)$, which has a comparable lifetime to methyl iodide. This species is thought to be produced in the tropical surface ocean as a result of biogenic activity, in particular from upwelling areas at the equator and on the coast of Africa [Atlas et al., 1993; Quack et al., 2004]. Although the traces of methyl iodide and bromoform are broadly similar, reflecting that both species can be produced from seawater, the former is generally better correlated with the dust events. (correlation with visibility is $r=-0.6$ for MeI and -0.3 for $\mathrm{CHBr}_{3}$ ). Event A shows no increase in bromoform, and while event B produces an effect in both species, event $\mathrm{C}$ again shows a stronger effect for methyl iodide.

\subsection{Backward Simulations}

[9] To examine the extent of causality in the covariance of dust and methyl iodide and to gauge the origin of the dust events, we performed backward simulations with the parti-

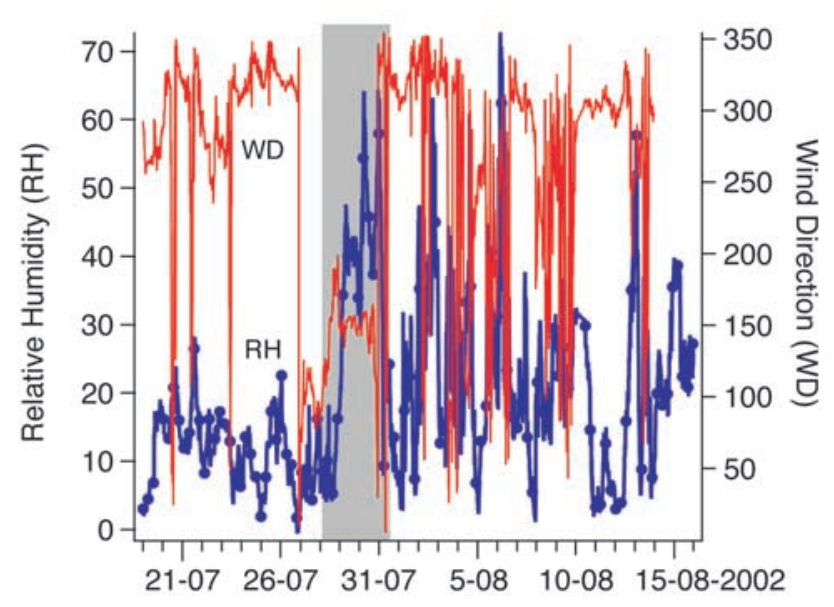

Figure 1b. Relative humidity $(\mathrm{RH})$ and wind direction (WD) measured at Izaña, Tenerife, plotted on the same timescale as that in Figure 1a. The period of the main dust event is marked with grey shading. 


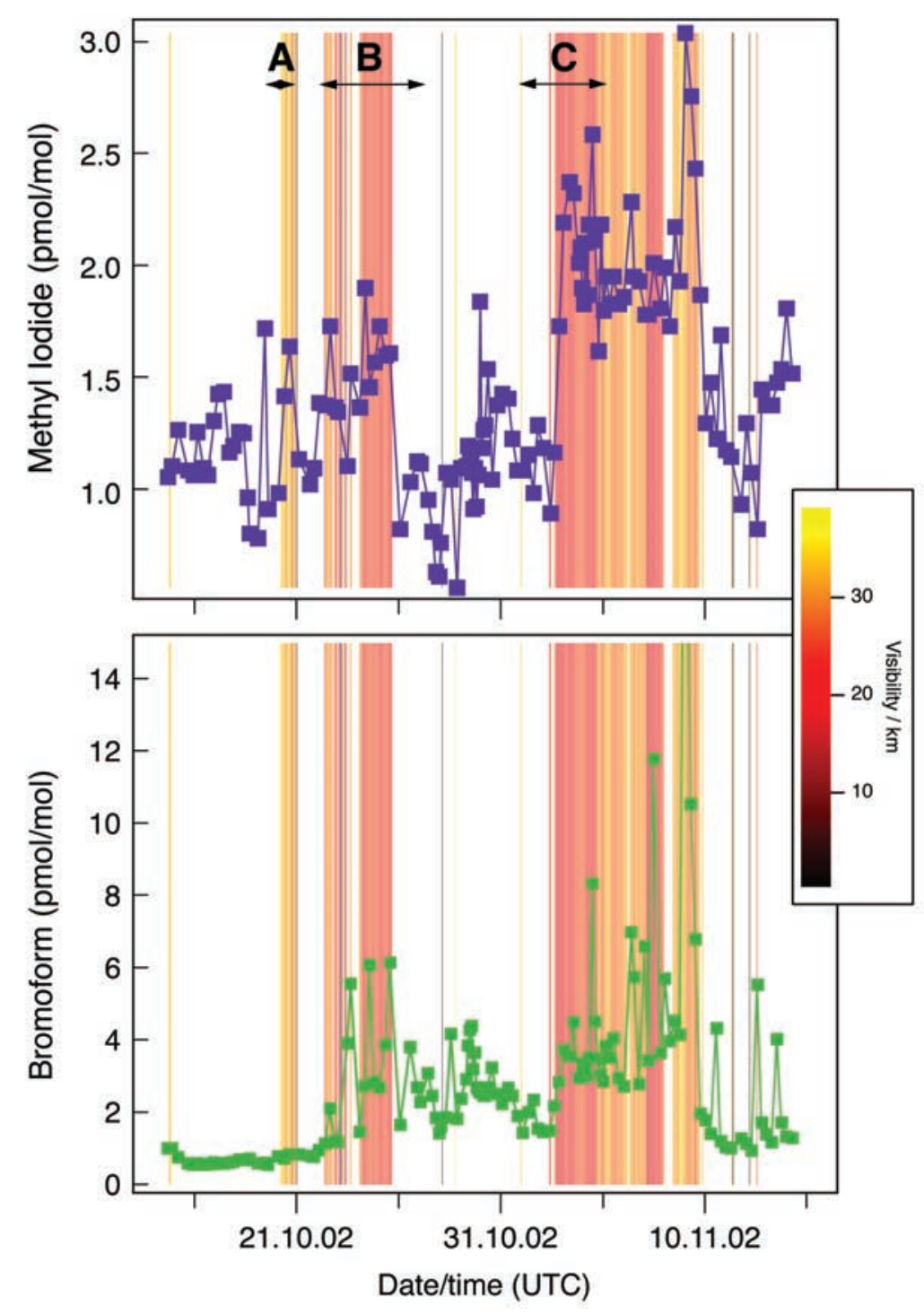

Figure 2. Methyl iodide and bromoform mixing ratios measured on the research ship Meteor plotted with visibility. Prolonged periods of low visibility (brown-red regions) correspond to high dust loadings. The letters $\mathrm{A}-\mathrm{C}$ refer to particular events described in the text.

cle dispersion model FLEXPART [Stohl et al., 1998], which has been validated in a number of studies on regional and long-range air pollution transport [e.g., Wotawa and Trainer, 2000; Forster et al., 2001, 2004]. The backward simulations are described in detail by Seibert and Frank [2004]. As FLEXPART parameterizes turbulence [Stohl and Thomson, 1999] and convection [Emanuel and Živcović-Rothman, 1999] and accounts for the filamentation of the initial sampling volume by the large-scale advection, the FLEXPART backward simulations are more accurate than traditional back trajectories [Stohl et al., 2002]. The simulations for this analysis were based on operational data from the European Centre for Medium-Range Weather Forecasts $(E C M W F)$, which have a horizontal resolution of $1^{\circ} \times 1^{\circ}$, 60 vertical levels, and a temporal resolution of 3 hours. 40000 particles with unit mixing ratio were released, exactly at the dust affected measurement point in Tenerife or at the ship's position respectively, every 3 hours, and calculated 15 days backward in time. While FLEXPART cannot resolve the local upslope winds at Tenerife it can indicate the origin and transport path of the dust-laden air masses to the mountain and the ship. Owing to the effects of turbulence and convection the particles build up a so-called retroplume. Every 24 hours the particle positions are assigned to one of five groups using a clustering algorithm [Stohl et al., 2002] in order to summarize the retroplume information into the five clusters and a trajectory of the centroid of the retroplume. Such a summary is shown in Figures $3 a-3 c$, and this illustrates the movement and mixing of dust-laden air prior to arriving at Tenerife (Figure 3a), at the ship in the mid-Atlantic (Figure 3b), and the ship near Africa (Figure 3c). The figures should be interpreted as follows. At the position of every cluster a circle is drawn with the circle's radius scaled with the 


\section{Retroplume summary} Dust event at Tenerife

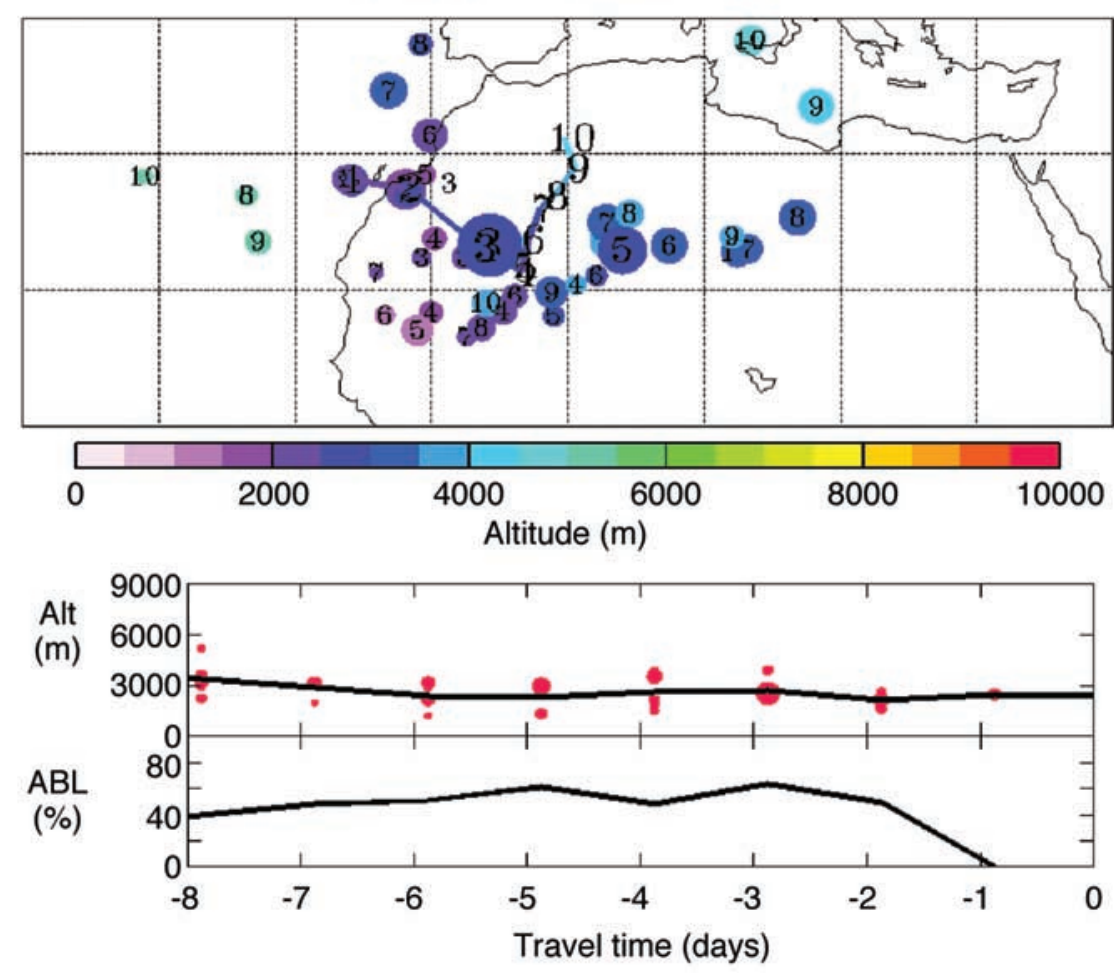

Figure 3a. The 15-day retroplume summary determined with the FLEXPART model for Tenerife, the main dust event (10 days are plotted).

number of particles the cluster represents (i.e., the fraction of sampled air for which it is representative). The color of the circle indicates the altitude, and the number on top gives the time backward in days. The retroplume's centroid is displayed by a trajectory. Also shown are time series of the mean altitude of the retroplume (and the five clusters, red circles in the time series, size again indicating the relative fraction of sampled air it represents), and the fraction of particles in the atmospheric boundary layer (ABL), which is defined by the mixing height from the ECMWF data at the time of the output, which is 15:00 UTC for the results shown in Figures $3 \mathrm{a}-3 \mathrm{c}$. Note that the information on the fraction of particles in the ABL must be interpreted carefully. Over land the mixing height is a very sensitive parameter and can vary considerably during the course of the day with the highest values in the early afternoon and the lowest values during nighttime. In the early afternoon, the mixing height over land areas is usually much higher than over the sea and can easily extent up to the trade wind inversion (around $3 \mathrm{~km}$ ) in summer. This is, for example, evident from the dust event over Tenerife in Figure $3 \mathrm{a}$, where up to $60 \%$ of the particles traveling over land are within the ABL. The fraction of particles within the ABL decreases substantially as soon as the particles travel over the sea toward Tenerife 2 to 1 days prior to arrival. For the ship cases only a very small fraction of the particles is within the ABL at 15 UTC. The ship measurements were taken in fall, when the sunset is earlier than in summer. Therefore the mixing height over land at 15 UTC is most likely already much lower than it was just one or two hours before. From the Figures $3 a-3 c$, we may deduce the most probable source region of the dust events. For the main dust event at Tenerife the FLEXPART trajectories show that 3 days previously a large proportion of the air sampled in the dust event originated from East Mauritania, as indicated by the largest circle marked 3 in Figure 3a. For the events encountered by ship, event B is shown by the large circle marked 10, to consist of air that was in the most part over southern Algeria 10 days previously. Similarly, event $C$ is shown to have occurred in air that had transected Algeria and Mauritania beneath the trade wind inversion (3-4 km), consistent with the prevailing northeasterly trade winds. For the Meteor ship samples it is clear from Figures $3 b$ and $3 c$ (see color code in the top panel and ABL\%) that there has been little influence from the upwelling zones prior to the descent into the marine boundary layer within the vicinity of the ship. During both dust events observed on ship the relative humidity decreased sharply. This supports the FLEXPART analysis that little mixing with marine boundary layer air or contact with the sea surface has occurred prior to measurement. Indeed, in all three cases air has descended from above the boundary layer to the point of measurement and has not in the recent past resided over the African coast.

[10] The proximity of the dust source region to the coast provides one possible explanation for the effects observed. Oceanic upwelling along the coastal regions of tropical West Africa brings nutrients to the surface and ocean biology proliferates as a result. Such regions are known to be a strong source of trace gases such as methyl iodide 


\section{Retroplume summary Dust event B on ship - open ocean}
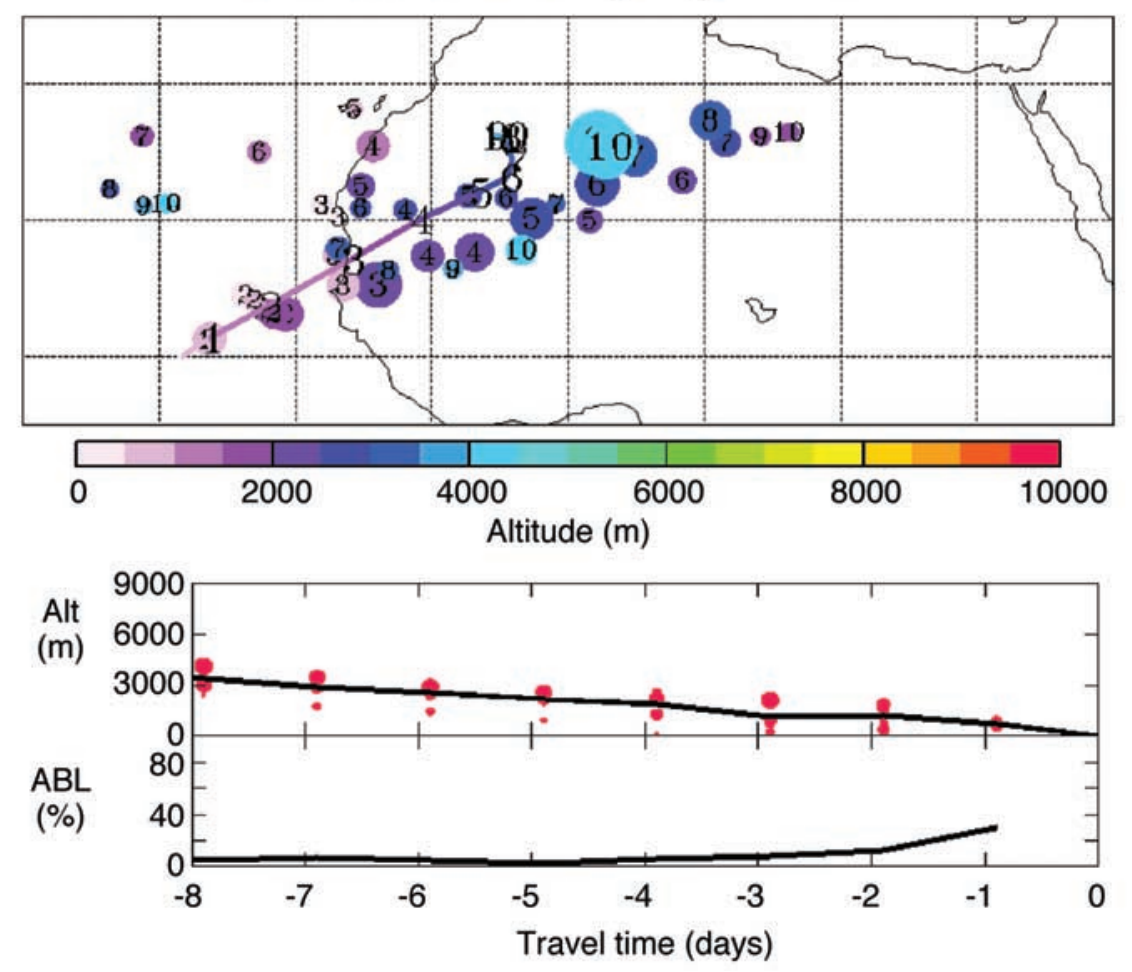

Figure 3b. The 15-day retroplume summary determined with the FLEXPART model for the ship in the mid-Atlantic (10 days are plotted), event B in Figure 2.

[Davis et al., 1996; Happell and Wallace, 1996], which could mix into dust-laden air. The explanation that the dust and methyl iodide sources are co-located is, however, not satisfactory for several reasons. Firstly, the effects were observed in two campaigns, and for only one (for Tenerife) is the dust source located near the coast. Secondly, in the case of Tenerife, dust poor air arriving at the mountain site Izaña from the southeast 1.5 days prior to the main dust event (see Figures 1a and 1b) passed over similar areas but did not show enhanced methyl iodide, precluding the influence of local upwelling. Finally, the backward simulations (Figures $3 a-3 c$ ) show that the long distance transport of dust from Africa to Tenerife and to the mid-Atlantic occurred mostly above the marine boundary layer without significant convective influence; and so mixing from upwelling related surface sources located close to the African coast, or input from the ocean en-route will be inhibited. Furthermore, prior to the dust loading the air did not reside over the upwelling zones. To summarize, we use the FLEXPART analysis here to (1) identify source regions, (2) to show no significant convection occurred en-route to the sampling site, (3) to establish that the air parcels did not reside for prolonged periods over the upwelling area, and (4) to locate from where the dust samples should be retrieved for laboratory experiments.

\subsection{Laboratory Experiments}

[11] To test the feasibility of dust triggering methyl iodide emissions upon contact with seawater, a simple dust-seawater addition experiment was first conducted in the labora- tory. For this a fine dust sample was collected from the region of southern Algeria (Oued Tamrassett, located in the Hoggar region), indicated as the dust source region in the FLEXPART analysis. The dust was determined to contain $4.7 \%$ iron using X-ray fluorescence spectrometry, and $0.19 \%$ total carbon using an infrared absorption analyzer (Eltra CS2000). Although the soluble iron fraction was not determined, this has been previously reported for Tropical Atlantic dust as 1\% [Johansen et al., 2000]. The dust was also analyzed for iodide by ion chromatography but was found in all experiments to be under the detection limit of $1 \mathrm{mg} / \mathrm{kg}$. Seawater $(10 \mathrm{ml})$ collected during the ship's cruise (Meteor 55) and filtered to $0.2 \mu \mathrm{m}$ was then added to the dust (4 g). As soon as 20 minutes after addition, methyl iodide production was found to occur. Although the experiments were not quantitative and the mechanism is not yet clear, this result shows that dust deposition to the sea or the wetting of dust with marine boundary layer water can stimulate rapid methyl iodide production. This was therefore considered a viable new explanation of the observed trends and was examined further.

[12] A series of laboratory experiments were performed to assess the abiotic methyl iodide production caused by dust input into the ocean, in particular with respect to iodide $\left(\mathrm{I}^{-}\right)$ and hydrogen peroxide $\left(\mathrm{H}_{2} \mathrm{O}_{2}\right)$, both of which are known to be present in surface seawater [Tsunogai, 1971; Croot et al., 2004a, 2004b]. In principle, we expected the natural concentrations of iron and organic carbon in the soil-dust (included in Table 1), to be sufficient for the formation of methyl iodide. Methyl iodide production was detected in all 


\section{Retroplume summary Dust event C on ship - near Africa}
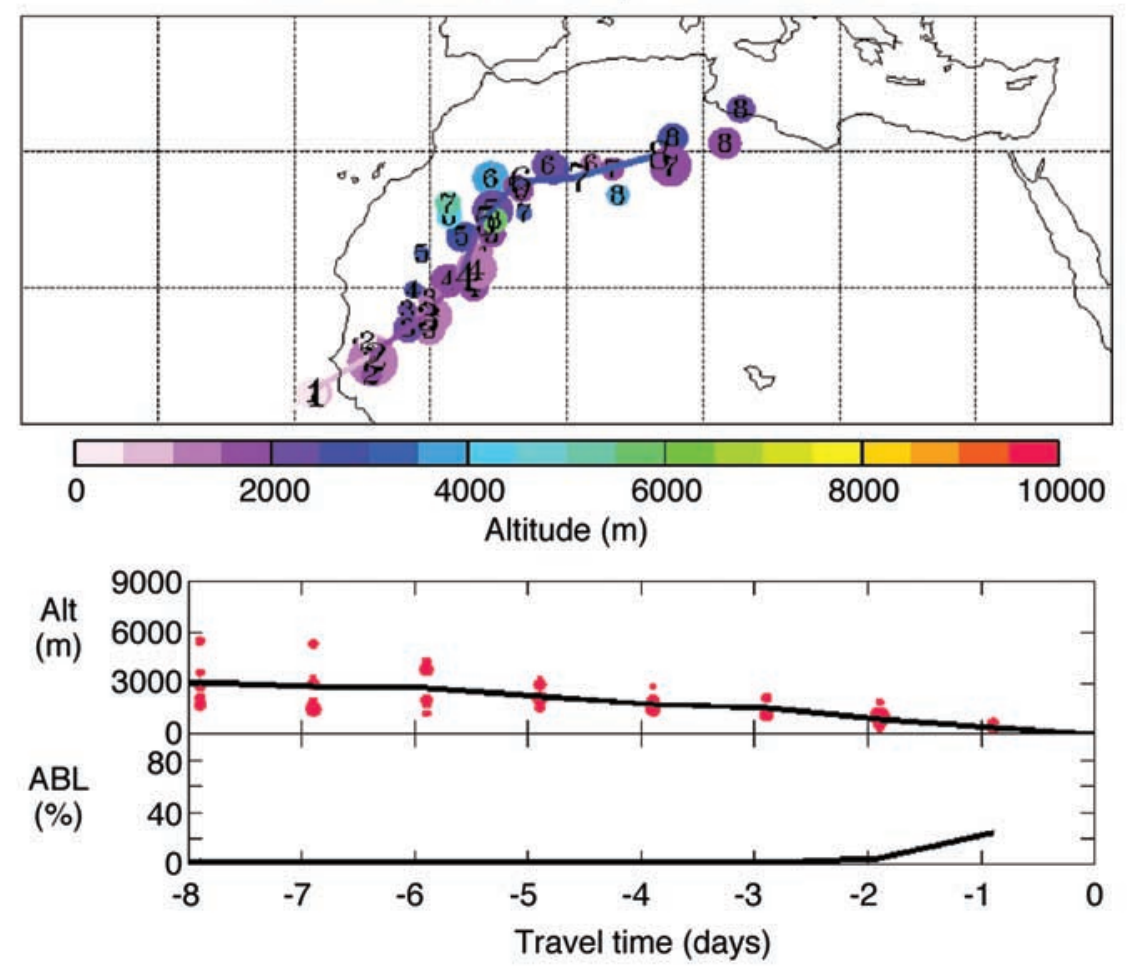

Figure 3c. The 15-day retroplume summary determined with the FLEXPART model for the near to the African coast (10 days are plotted), event $\mathrm{C}$ in Figure 2.

of the samples of soil dust suspended in UV irradiated water, albeit to different extents. The lowest values were obtained in the samples that were suspended in bi-distilled water without addition of further components; see Table 1. A distinct increase in the $\mathrm{CH}_{3} \mathrm{I}$ concentrations was observed after addition of iodide (in the form of potassium iodide). An even higher yield was achieved through the addition of potassium iodide in combination with hydrogen peroxide; see Figure 4. The $\mathrm{CH}_{3} \mathrm{I}$ concentrations are in general proportional to the amount of KI added. Since formation of methyl iodide was also demonstrated in the experiments with the sterilized samples, and the yields were comparable to the results from the other analyses, the microbiological contribution to these methyl iodide yields was assumed to be negligible.

[13] In summary, methyl iodide production occurred in all of the experiments without further addition of organic carbon or iron(III). Since some methyl iodide production occurred even when the dust was wetted with bi-distilled water (not only with seawater), there must also be some iodide in the dust, although the iodide content in the dust was below the detection limit of our analytical system. It should be noted that concentrations of iodide in the surface ocean in this region are circa $100 \mathrm{nM}$ [Campos et al., 1996; Truesdale et al., 2000] and therefore there is probably much more iodide available in the surface ocean than in dustladen air. The yields of methyl iodide increased after application of KI and $\mathrm{H}_{2} \mathrm{O}_{2}$. Since both iodide and $\mathrm{H}_{2} \mathrm{O}_{2}$ are present in seawater we conclude that an input of iron containing mineral dust can lead to abiotic production of methyl iodide, at the ocean surface.

\section{Discussion}

[14] Two data sets have shown an unexpected correlation between methyl iodide mixing ratios and dust. Five possible explanations for this have been considered: (1) Dust storms from Africa were advected over upwelling regions, with high nutrients, biological activity, and methyl iodide fluxes. The proximity of the dust and methyl iodide source leads to a coincidental correlation. (2) The dust storm is associated with high wind speeds or convection and therefore enhanced mixing with sea surface and the dust storm occurred. (3) Dust attenuates sunlight to prolong the atmospheric lifetime of methyl iodide within the dust storm, and hence apparent production. (4) The dust stimulates methyl iodide emission from the ocean surface. (5) Methyl iodide is produced directly from the dust aerosol.

[15] On the basis of the arguments presented above, we have determined the first explanation to be unlikely. However, to further test this hypothesis a further 30 canisters were taken directly over the upwelling area west of Mauritania and analyzed using the same GC-MS system. The mean, median, maximum, and standard deviation of the samples are: $2.05,1.85,4.11$, and $0.73 \mathrm{pmol} / \mathrm{mol}$, respectively. Similar mean values ( 2 pptv) have been reported on cruise across the oligotrophic North Atlantic [Chuck et al., 2005]. Although some high concentrations are indeed 
Table 1. Summary of the Methyl Iodide Yields From the Dust, Iodide ( $\left.\mathrm{I}^{-}\right)$, and Hydrogen Peroxide $\left(\mathrm{H}_{2} \mathrm{O}_{2}\right)$ Addition Experiments ${ }^{\mathrm{a}}$

\begin{tabular}{|c|c|c|c|c|c|c|c|}
\hline Number & Sterile? & $\mathrm{KL}$, mmol & $\mathrm{H}_{2} \mathrm{O}_{2}, \mu \mathrm{L}$ & $\mathrm{H}_{2} \mathrm{O}, \mathrm{mL}$ & Mel, nmol/L & $\mathrm{Fe}, \%$ & $\mathrm{C}_{\text {org }}, \%$ \\
\hline \multicolumn{8}{|c|}{ L1 } \\
\hline 1 & no & - & - & 10 & 5.2 & 5.3 & 0.1343 \\
\hline 2 & no & 10 & 200 & 10 & 25.4 & - & - \\
\hline \multicolumn{8}{|c|}{$L 2$} \\
\hline 3 & no & - & - & 10 & 2.4 & 8.7 & 1.2525 \\
\hline 4 & no & 10 & 200 & 10 & 61.9 & - & - \\
\hline \multicolumn{8}{|c|}{$L 3$} \\
\hline 5 & no & - & - & 10 & 3.7 & 6.4 & 0.4273 \\
\hline 6 & no & 10 & 200 & 10 & 20.1 & - & - \\
\hline \multicolumn{8}{|c|}{ L4 } \\
\hline \multirow{2}{*}{\multicolumn{8}{|c|}{ L5 }} \\
\hline & & & & & & & \\
\hline 9 & no & - & - & 10 & 3.6 & 4.2 & 0.0946 \\
\hline 10 & no & 10 & 200 & 10 & 24.7 & - & - \\
\hline \multicolumn{8}{|c|}{ L6 } \\
\hline 11 & no & - & - & 10 & 1.5 & 4.36 & 1.0705 \\
\hline 12 & no & 10 & - & 10 & 83.0 & - & - \\
\hline 13 & no & 10 & 200 & 10 & 87.8 & - & - \\
\hline 14 & yes & - & - & 10 & 0.8 & - & - \\
\hline 15 & yes & 10 & 200 & 10 & 76.8 & - & - \\
\hline \multicolumn{8}{|c|}{$L 7$} \\
\hline 16 & no & - & - & 10 & 4.4 & 5.9 & 1.1868 \\
\hline 17 & no & 10 & 200 & 10 & 79.3 & - & - \\
\hline \multicolumn{8}{|c|}{$L 8$} \\
\hline 18 & no & - & - & 10 & 3.3 & 0.1 & 2.031 \\
\hline 19 & no & 10 & 200 & 10 & 11.8 & - & - \\
\hline
\end{tabular}

${ }^{\mathrm{a}}$ The iron and carbon contents of the dust samples are also included.

detected in the upwelling region this source is clearly spatially and temporally variable and therefore again unlikely to account for the consistent correlations between dust and methyl iodide observed in both data sets. In section 3.2, it was noted that bromoform during the dust event close to the upwelling areas (event $\mathrm{C}$ ), was lower than observed in the mid-Atlantic dust storm (event B). This too hints at another source for methyl iodide other than the upwelling regions that are thought to be strong sources of bromoform. The second explanation, that enhanced wind speeds or convection has induced strong fluxes from the ocean surface and mixed up methyl iodide from the sea surface is not supported by the in situ wind speed data, which are not elevated in the dust event (see Figure 1a expanded section), or the FLEXPART trajectories (Figures $3 \mathrm{a}-3 \mathrm{c}$ ), which on the basis of ECMWF meteorological data show no evidence of significant convection en route to the point of sampling. For the third explanation to be true (reduced photolysis in dust), light levels in the dust storm must be significantly reduced, as methyl iodide in the main dust event at Tenerife was circa 10 times the concentration before and after. Photolysis measurements made at Tenerife during this event have shown only small decreases $(<5 \%)$ in $\mathrm{JO}^{1} \mathrm{D}$ and $\mathrm{JNO}_{2}$ [de Reus et al., 2005] and little effect on the local photochemistry of oxygenated organic species was found [Salisbury et al., 2006]. Furthermore, assuming a methyl iodide photolysis rate of $3 \times 10^{-6} \mathrm{~s}^{-1}$ [Roehl et al., 1997], we may calculate that the time taken for factor of 10 differ- ence to be generated. This is approximately 9 days, which is far longer than the transport time from the coast to the point of measurement, further evidence against the upwelling source explanation for the observed changes. The combined field data analysis and laboratory experiments therefore indicate that dust-stimulated emission of methyl iodide from the ocean is a plausible explanation for the observed effects.

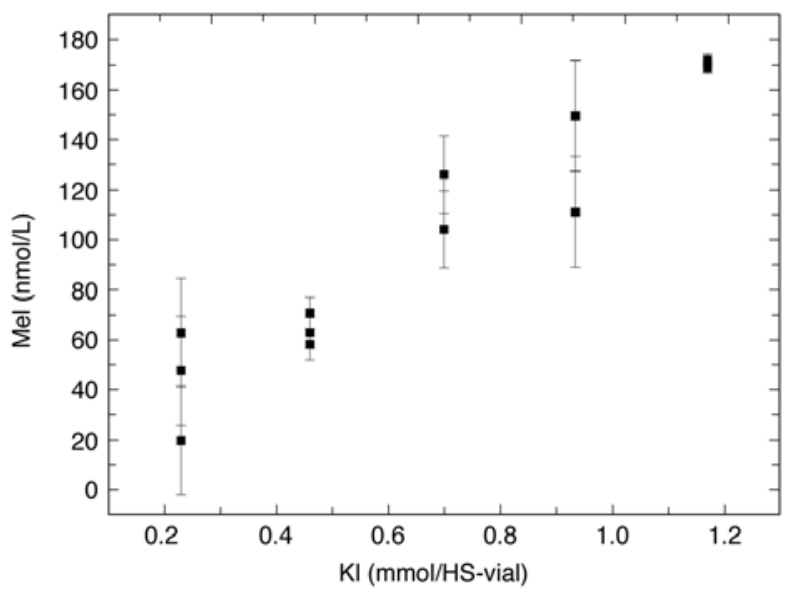

Figure 4. The emission of methyl iodide from dust upon addition of iodide $\left(\mathrm{I}^{-}\right)$and hydrogen peroxide as a function of the concentration. 


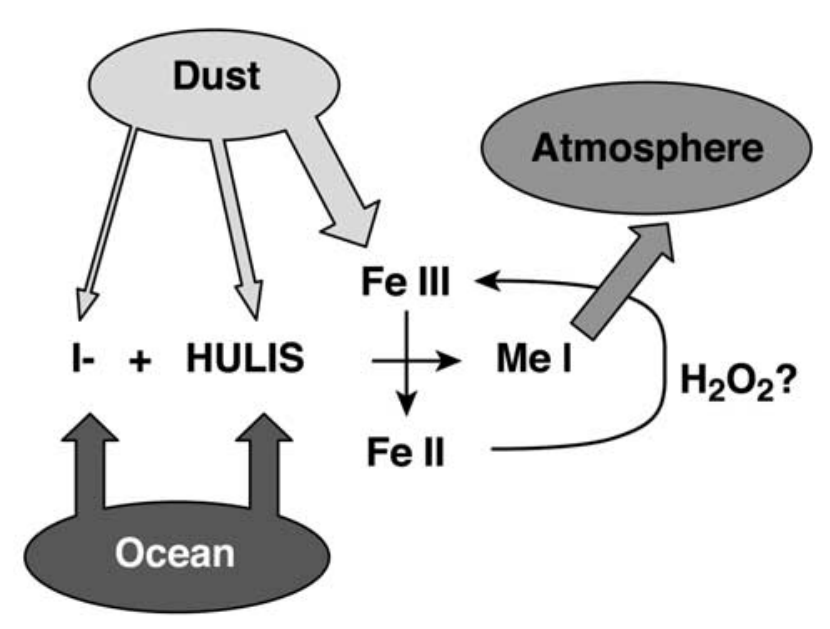

Figure 5. A schematic diagram of the proposed abiotic production mechanism for methyl iodide.

Could the emission of the methyl iodide emission be biological, and the result of marine plankton growth being stimulated through dust deposition? In event B (Figure 2) the dust descended from above the boundary layer to the ship and a methyl iodide signal enhancement was seen immediately. Moreover, in all events the dust and methyl iodide show simultaneous enhancements. We contend that a biological response would require some incubation time (1-2 days) before an enhanced emission could be potentially observed. Furthermore, the laboratory experiments described in section 3.4 show that emission can proceed abiotically. We must therefore now consider how this effect may occur.

[16] Surface seawater contains some iodide, $\mathrm{H}_{2} \mathrm{O}_{2}$ and complex organic species collectively termed humic-like substances (HULIS). This is also true of soil, in which iodide concentrations are even enriched with respect to seawater, and HULIS-like compounds are also abundant. Recent experiments on soil samples have revealed that methyl iodide can be formed via an abiotic redox mechanism [Keppler et al., 2000, 2003; Schöler and Keppler, 2003]. It was shown that in soils, in the presence of an oxidizing agent such as iron III, and with the addition of iodide, methyl iodide can be formed efficiently. Such reactions could also occur in seawater, provided that a suitable oxidizing agent such as iron III was present. Under normal conditions the surface seawater is very poor in iron, indeed iron supply is the limiting factor for phytoplankton growth over vast areas of the ocean. Therefore dust deposition to the ocean has been long recognized as an important factor in the biogeochemical cycle of iron [Jickells et al., 2005, and references therein]. The dust collected for this work contained $4.7 \%$ iron, of which probably $1 \%$ is in soluble form. Recent measurements of dissolved iron (DFe) in Tropical Atlantic seawater have established that Saharan dust events can provide significant amounts of DFe and that the residence time for iron in surface seawater can be as short as 6 days [Croot et al., 2004a]. At this point, it is worth recalling that the laboratory experiments have shown that with $\mathrm{H}_{2} \mathrm{O}_{2}$ higher yields of methyl iodide were obtained. One possible explanation for this would be that the $\mathrm{H}_{2} \mathrm{O}_{2}$ reconverts $\mathrm{Fe}$ II to $\mathrm{Fe}$ III, thus making the available iron more effective. This effect has been previously seen to occur in rainwater [Deutsch et al., 2001]. Therefore dust and seawater can provide the ingredients (Fe, $\mathrm{I}^{-}$, HULIS) necessary for a substitution reaction to occur, shown schematically in Figure 5, and methyl iodide to be produced. HULIS model compounds used in soil studies suggest this reaction involved methoxy groups in a reverse Williamson-type reaction, that is, HULIS-O- $\mathrm{CH}_{3}+$ $\mathrm{I}^{-}\left(+\mathrm{H}^{+}\right)->$HULIS-OH $+\mathrm{CH}_{3} \mathrm{I}$. This is different to the mechanism proposed by Moore and Zafiriou [1994], who suggested that a radical recombination of $\mathrm{CH}_{3} \bullet$ and I• followed UV photolysis of carbon-carbon bonds. Indeed, the strong correlation of surface water $\mathrm{CH}_{3} \mathrm{I}$ levels with incident light noted in several field data sets, supported this view until recently. However, seawater incubation experiments performed by Richter and Wallace [2004] with low UV intensities showed no significant difference in $\mathrm{CH}_{3} \mathrm{I}$ concentrations, suggesting that the substitution mechanism proposed here should be considered. Richter and Wallace [2004] also made underway seawater measurements of methyl iodide from 5-m depth during the Meteor cruise, but these did not show a clear correlation with dust. Furthermore, we have estimated the seawater concentration required to generate $1-1.5 \mathrm{pmol} / \mathrm{mol}$ (pptv) enhancements in atmospheric methyl iodide in both Tenerife and on the Meteor, and found them to be more than double those measured at 5-m depth from the Meteor [Richter, 2004]. Either the main production of methyl iodide is occurring rapidly within the first $5 \mathrm{~m}$ of the ocean or an alternative explanation for methyl iodide generation must be sought.

[17] Thus far we have proposed that dust deposition to the ocean surface triggers rapid release of methyl iodide. The same reactions could also be occurring on the aerosols themselves, provided that dust, which contains iron, organic species (in our dust sample $0.19 \%$ total carbon), and some traces of iodide, is exposed to water, iodide from seawater or iodide from the oxidization of iodine species. Such aerosol could be generated from surface seawater into which dust has recently fallen. Another possibility is that moist sea salt aerosol and dust coalesce, although this is statistically unlikely as both particle types are of similar size and therefore unlikely to collide frequently. A final possibility is that water from marine boundary layer air condenses on airborne dust, or on dust that has accumulated on the ground. Since the dust contains some trace iodide, mixing with boundary layer water and deposition of $\mathrm{H}_{2} \mathrm{O}_{2}$ from ambient air could also stimulate the emission of methyl iodide in a manner similar to the laboratory experiments described in section 3.4. In the case of Tenerife it is difficult to determine which mechanism, either sea surface contact or on aerosol is more likely. We favor the idea that the dust stimulates methyl iodide emission at the sea surface and stronger mixing from the marine boundary layer evidenced by the higher humidity, brings the methyl iodide to the site. The methyl iodide peaks measured at Izaña shortly after the dust event (2-5 August), when high relative humidities and low ambient temperatures were experienced in the absence of airborne dust, could be the result of postdust biological enhancement in the seawater combined with a short-term enhancement in mixing, although this is admittedly somewhat speculative. 
[18] Inclusion of the mechanism proposed here in iodine aerosol models may help explain the unexpected $\mathrm{I}^{-}$and $\mathrm{IO}_{3}^{-}$ ratios observed by Baker [2004]. Previous estimates of the net oceanic emission of methyl iodide to the atmosphere have ranged from 130-1300 $\mathrm{Gg} \mathrm{yr}^{-1}$ [Campos et al., 1996; Rasmussen et al., 1982]. The most recent estimate, based on 3-D modeling and all available published oceanic data sets is $214 \mathrm{Gg} \mathrm{yr}^{-1}$ [Bell et al., 2002]. Since dust-stimulated emission of methyl iodide, was not specifically considered in these estimates we expect future estimates to be slightly higher. Dust-impacted regions of the ocean for which there is little or no data available are probably underestimated, although the overall budget increases will probably be modest, since the global model estimates were constrained by atmospheric measurements. If redox reactions of the type proposed here do occur on aerosol, then methyl iodide can be recycled and therefore has a longer effective atmospheric lifetime. Consequently, if the global budget is currently closed, then this suggests the presence of a further or stronger sink than previously thought.

[19] Further work is needed to assess the importance of dust stimulated methyl iodide emissions, and possible further links between dust, and the chemistry of sea and air. Such effects are perhaps more readily seen in methyl iodide, owing to its high photolysis rate and hence low background. However, the budgets of methyl bromide and methyl chloride may also be subtly affected. Significant enhancements were not seen for these or any other species in the data sets presented here, although small effects would be harder to discern as most other organohalogens measured (e.g., methyl bromide and methyl chloride) have appreciable and variable background concentrations. Because of the stochastic nature of these dust events, long-term measurements in dust-affected regions will be necessary (e.g., at Cape Verde or Canary Islands). Interestingly, a long-term data set of methyl iodide from Cape Grim, Tasmania has been published recently [Cohan et al., 2003; Cox et al., 2005]. The authors showed that elevated methyl iodide was observed in northerly winds that blew from mainland Australia across the Bass straight. Although not examined specifically in the papers, this region will most likely be the most impacted by dust from the mainland, particularly in the summer when methyl iodide emission were reported to be highest. Further south in the Southern Ocean, methyl iodide was measured by Wingenter et al. [2004] as part of an iron enrichment experiment in which large quantities of $\mathrm{FeSO}_{4}$ was added to the seawater. Measurements were made 48 hours after the iron was put in the ocean, and surprisingly showed a decrease in methyl iodide in the water. This appears to contradict the mechanism proposed here; however, the time frame of the measurement, oxidation state of the iron, or biology may have a deciding influence. A similar study in the same region showed an increase on methyl iodide on iron addition [Liss et al., 2005]. Detailed laboratory experiments are required to determine the production mechanism dependence on variables such as light, $\mathrm{pH}$, other catalysts and temperature. In summary, we point to a new link between dust and the iodine cycle and urge further study. Specialists from ocean, air, and aerosol science will need to work closely together in future for such effects to be quantified.
[20] Acknowledgments. We are grateful to Rolf Hofmann for help in the preparation of canisters and GC maintenance. Hermann Bange and the Meteor crew are thanked for logistical assistance. All three reviewers are thanked for their helpful comments. The Meteor cruise was funded by the DFG (grants WA 143/3 and WI 2130/1-1). The Tenerife work was part of the EU-funded project MINATROC, and the analysis was part of the preparation for the EU project OOMPH.

\section{References}

Atlas, E., W. Pollock, J. Greenberg, L. Heidt, and A. M. Thompson (1993), Alkyl nitrates, nonmethane hydrocarbons, and halocarbon gases over the equatorial Pacific Ocean during SAGA-3, J. Geophys. Res., 98, 16,933$16,947$.

Baker, A. R. (2004), Inorganic iodine speciation in tropical Atlantic aerosol, Geophys. Res. Lett., 31, L23S02, doi:10.1029/2004GL020144.

Baker, A. R., S. M. Turner, W. J. Broadgate, A. Thompson, G. B. Mcfiggans, O. Vesperini, P. D. Nightingale, P. S. Liss, and T. D. Jickells (2000), Distribution and sea-air fluxes of biogenic trace gases in the eastern Atlantic Ocean, Global Biogeochem. Cycles, 14(3), 871-886.

Bell, N., L. Hsu, D. J. Jacob, M. G. Schultz, D. R. Blake, J. H. Butler, D. B. King, J. M. Lobert, and E. Maier-Reimer (2002), Methyl iodide: Atmospheric budget and use as a tracer of marine convection in global models, J. Geophys. Res., 107(D17), 4340, doi:10.1029/2001JD001151.

Blake, N. J., et al. (1999), Aircraft measurements of the latitudinal, vertical, and seasonal variations of NMHCs, methyl nitrate, methyl halides, and DMS during the First Aerosol Characterization Experiment (ACE 1), J. Geophys. Res., 104, 21,803-21,817.

Campos, M. L., A. M. Farrenkopf, T. D. Jickells, and G. W. Luther III (1996), A comparison of dissolved iodine cycling at the Bermuda Atlantic Time-series Station and Hawaii Ocean Time-series Station, Deep Sea Res., Part II, 43, 455-466.

Carpenter, L. J. (2003), Iodine in the marine boundary layer, Chem. Rev., 103(12), 4953-4962.

Carpenter, L. J., G. Malin, P. S. Liss, and F. C. Kupper (2000), Novel biogenic iodine-containing trihalomethanes and other short-lived halocarbons in the coastal East Atlantic, Global Biogeochem. Cycles, 14(4), $1191-1204$

Chuck, A. L., S. M. Turner, and P. S. Liss (2005), Oceanic distributions and air-sea fluxes of biogenic halocarbons in the open ocean, J. Geophys. Res., 110, C10022, doi:10.1029/2004JC002741.

Cohan, D. S., G. A. Sturrock, A. P. Biazar, and P. J. Fraser (2003), Atmospheric methyl iodide at Cape Grim, Tasmania, from AGAGE observations, J. Atmos. Chem., 44(2), 131-150.

Cox, M. L., G. A. Sturrock, P. J. Fraser, S. T. Siems, and P. B. Krummel (2005), Identification of regional sources of methyl bromide and methyl iodide from AGAGE observations at Cape Grim, Tasmania, J. Atmos. Chem., 50(1), 59-77.

Croot, P. L., P. Streu, and A. R. Baker (2004a), Short residence time for iron in surface seawater impacted by atmospheric dry deposition from Saharan dust events, Geophys. Res. Lett., 31, L23S08, doi:10.1029/ 2004GL020153.

Croot, P. L., P. Streu, I. Peeken, K. Lochte, and A. R. Baker (2004b), Influence of the ITCZ on $\mathrm{H}_{2} \mathrm{O}_{2}$ in near surface waters in the equatorial Atlantic Ocean, Geophys. Res. Lett., 31, L23S04, doi:10.1029/ 2004GL020154.

Davis, D., J. Crawford, S. Liu, S. McKeen, A. Bandy, D. Thornton, F. Rowland, and D. Blake (1996), Potential impact of iodine on tropospheric levels of ozone and other critical oxidants, J. Geophys. Res., 101, $2135-2147$

de Reus, M., H. Fischer, R. Sander, V. Gros, R. Kormann, G. Salisbury, R. Van Dingenen, J. Williams, M. Zöllner, and J. Lelieveld (2005), Observations and model calculations of trace gas scavenging in a dense Saharan dust plume during MINATROC, Atmos. Chem. Phys., 5, $1787-1803$

Deutsch, F., P. Hoffmann, and H. M. Ortner (2001), Field experimental investigations on the $\mathrm{Fe}(\mathrm{II})-$ and $\mathrm{Fe}(\mathrm{III})$-content in cloudwater samples, J. Atmos. Chem., 40(1), 87-105.

Emanuel, K. A., and M. Zivcović-Rothman (1999), Development and evaluation of a convection scheme for use in climate models, J. Atmos. Sci., $56,1766-1782$

Forster, C., et al. (2001), Transport of boreal forest fire emissions from Canada to Europe, J. Geophys. Res., 106, 22,887-22,906.

Forster, C., et al. (2004), Lagrangian transport model forecasts and a transport climatology for the Intercontinental Transport and Chemical Transformation 2002 (ITCT 2k2) measurement campaign, J. Geophys. Res., 109, D07S92, doi:10.1029/2003JD003589.

Gros, V., J. Williams, G. Salisbury, J. van Aardenne, M. Lawrence, R. von Kuhlmann, R. Hofmann, M. Krol, H. Berresheim, and J. Lelieveld 
(2003), On the origins of anthropogenic hydrocarbons and halocarbons measured in the summertime European outflow on Crete 2001, Atmos. Chem. Phys., 3, 1893-1923.

Happell, J. D., and D. W. R. Wallace (1996), Methyl iodide in the Greenland/Norwegian Seas and the tropical Atlantic Ocean: Evidence for photochemical production, Geophys. Res. Lett., 23(16), 2105-2108.

Jickells, T. D., et al. (2005), Global iron connections between desert dust, ocean biogeochemistry, and climate, Science, 308(5718), 67-71.

Johansen, A. M., R. L. Siefert, and M. R. Hoffmann (2000), Chemical composition of aerosols collected over the tropical North Atlantic Ocean, J. Geophys. Res., 105, 15,277-15,312.

Keppler, F., R. Eiden, V. Niedan, J. Pracht, and H. F. Schöler (2000), Halocarbons produced by natural oxidation processes during degradation of organic matter, Nature, 403(6767), 298-301.

Keppler, F., R. Borchers, P. Elsner, I. Fahimi, J. Pracht, and H. F. Schöler (2003), Formation of volatile iodinated alkanes in soil: Results from laboratory studies, Chemosphere, 52(2), 477-483.

Liss, P., A. Chuck, D. Bakker, and S. Turner (2005), Ocean fertilization with iron: Effects on climate and air quality, Tellus, Ser. B, 57, 269-271.

Moore, R. M., and W. Groszko (1999), Methyl iodide distribution in the ocean and fluxes to the atmosphere, J. Geophys. Res., 104, 11,16311,171 .

Moore, R. M., and O. C. Zafiriou (1994), Photochemical production of methyl-iodide in seawater, J. Geophys. Res., 99, 16,415-16,420.

O’Dowd, C. D., J. L. Jimenez, R. Bahreini, R. C. Flagan, J. H. Seinfeld, K. Hameri, L. Pirjola, M. Kulmala, S. G. Jennings, and T. Hoffmann (2002), Marine aerosol formation from biogenic iodine emissions, Nature, 417(6889), 632-636.

Quack, B., E. Atlas, G. Petrick, V. Stroud, S. Schauffler, and D. W. R. Wallace (2004), Oceanic bromoform sources for the tropical atmosphere, Geophys. Res. Lett., 31, L23S05, doi:10.1029/2004GL020597.

Rasmussen, R. A., M. Khalil, R. Gunawardena, and S. D. Hoyt (1982), Atmospheric methyl-iodide (CH3I), J. Geophys. Res., 87, 3086-3090.

Richter, U. (2004), Factors influencing methyl iodide production in the ocean and its flux to the atmosphere, Ph.D. dissertation, Mar. Biogeochem. Res. Div., Univ. of Kiel, Kiel, Germany. (Available at http:// e-diss.uni-kiel.de/diss 1024.)

Richter, U., and D. W. $\bar{R}$. Wallace (2004), Production of methyl iodide in the tropical Atlantic Ocean, Geophys. Res. Lett., 31, L23S03, doi:10.1029/2004GL020779.

Roehl, C. M., J. B. Burkholder, G. K. Moortgat, A. R. Ravishankara, and P. J. Crutzen (1997), Temperature dependence of UV absorption cross sections and atmospheric implications of several alkyl iodides, J. Geophys. Res., 102, 12,819-12,829.

Salisbury, G., J. Williams, R. van Dingenen, V. Gros, S. Bartenbach, X. Xu, H. Fischer, R. Kormann, M. de Reus, and M. Zöllner (2006), Assessing the effect of a Saharan dust storm on oxygenated organic compounds at Izaña, Tenerife (July-August 2002), J. Geophys. Res., 111, D22303, doi:10.1029/2005JD006840.

Scarratt, M. G., and R. M. Moore (1999), Production of chlorinated hydrocarbons and methyl iodide by the red microalga Porphyridium purpureum, Limnol. Oceanogr., 44(3), 703-707.

Schauffler, S. M., E. L. Atlas, S. G. Donnelly, A. Andrews, S. A. Montzka, J. W. Elkins, D. F. Hurst, P. A. Romashkin, G. S. Dutton, and V. Stroud (2003), Chlorine budget and partitioning during the Stratospheric Aerosol and Gas Experiment (SAGE) III Ozone Loss and Validation Experiment (SOLVE), J. Geophys. Res., 108(D5), 4173, doi:10.1029/2001JD002040.

Schöler, H. F., and F. Keppler (2003), Abiotic formation of organohalogens in the terrestrial environment, Chimia, 57(1-2), 33-34.
Seibert, P., and A. Frank (2004), Source-receptor matrix calculation with a Lagrangian particle dispersion model in backward mode, Atmos. Chem. Phys., 4, 51-63.

Stohl, A., and D. J. Thomson (1999), A density correction for Lagrangian particle dispersion models, Boundary Layer Meteorol., 90, 155-167.

Stohl, A., M. Hittenberger, and G. Wotawa (1998), Validation of the Lagrangian particle dispersion model FLEXPART against large scale tracer experiment data, Atmos. Environ., 32, 4245-4264.

Stohl, A., S. Eckhardt, C. Forster, P. James, N. Spichtinger, and P. Seibert (2002), A replacement for simple back trajectory calculations in the interpretation of atmospheric trace substance measurements, Atmos. Environ., 36, 4635-4648.

Truesdale, V. W., A. J. Bale, and E. M. S. Woodward (2000), The meridional distribution of dissolved iodine in near-surface waters of the Atlantic Ocean, Prog. Oceanogr., 45, 387-400.

Tsunogai, S. (1971), Iodine in the deep water of the ocean, Deep Sea Res. $18,913-919$

Vogt, R., R. Sander, R. von Glasow, and P. Crutzen (1999), Iodine chemistry and its role in halogen activation and ozone loss in the marine boundary layer: A model study, J. Atmos. Chem., 32, 375-395.

Wallace, D. W. R., and H. W. Bange (2004), Introduction to special section: Results of the Meteor 55: Tropical SOLAS Expedition, Geophys. Res. Lett., 31, L23S01, doi:10.1029/2004GL021014.

Williams, J., R. Holzinger, V. Gros, X. Xu, E. Atlas, and D. W. R. Wallace (2004), Measurements of organic species in air and seawater from the tropical Atlantic, Geophys. Res. Lett., 31, L23S06, doi:10.1029/ 2004GL020012.

Wingenter, O. W., K. B. Haase, P. Strutton, G. Friederich, S. Meinardi, D. R. Blake, and F. S. Rowland (2004), Changing concentrations of CO, CH4, $\mathrm{C} 5 \mathrm{H} 8, \mathrm{CH} 3 \mathrm{Br}, \mathrm{CH} 3 \mathrm{I}$, and dimethyl sulfide during the southern ocean iron enrichment experiments, Proc. Natl. Acad. Sci. U. S. A., 101(23), $8537-8541$

Wotawa, G., and M. Trainer (2000), The influence of Canadian forest fires on pollutant concentrations in the United States, Science, 288, 324-328.

Yokouchi, Y., Y. Nojiri, L. A. Barrie, D. Toom-Sauntry, and Y. Fujinuma (2001), Atmospheric methyl iodide: High correlation with surface seawater temperature and its implications on the sea-to-air flux, J. Geophys. Res., 106, 12,661-12,668.

E. Atlas, Rosenstiel School of Marine and Atmospheric Science, University of Miami, Miami, FL 33149, USA.

A. Batsaikhan, K. Maciejczyk, and H. F. Schöler, Institute of Environmental Geochemistry, University of Heidelberg, D-69120 Heidelberg, Germany.

C. Forster, Norwegian Institute for Air Research, N-2027 Kjeller, Norway.

V. Gros, CNRS, Laboratoire des Sciences du Climat et de l'Environnement (L.S.C.E.), Orme des Merisiers, Bat. 701, Gif sur Yvette, 91 191, France.

B. Quack, Forschungsbereich Marine Biogeochemie, Leibniz Institut für Meereswissenschaften, 24148 Kiel, Germany.

R. Sander, J. Williams, and N. Yassaa, Max Planck Institute for Chemistry, D-55128 Mainz, Germany. (williams@mpch-mainz.mpg.de)

R. Van Dingenen, Climate Change Unit, Institute for Environment and Sustainability, T.P. 290, European Commission, Joint Research Centre, I-21020 Ispra (VA), Italy. 